\title{
MEMAHAMI FORMASI POLITIK GERAKAN PENEGAKAN SYARIAT ISLAM DI MAKASSAR
}

\section{Understanding the Political Formation of Islamic Law Movement Empowerment in Makassar}

\author{
Abdul Aziz \\ Sekolah Tinggi Agama Islam Negeri (STAIN) Watampone \\ Jl. HOS Cokroaminoto Watampone \\ Email: abdulaziz18@rocketmail.com
}

Naskah diterima tanggal 29 Juni 2015. Naskah direvisi tanggal 13 Juli 2015 Naskah disetujui tanggal 03 November 2015.

\begin{abstract}
Abstrak
Tulisan ini adalah hasil penelitian yang mengkaji tentang politik syariat Islam di Makassar pada kurun waktu 2001-2005. Penelitian ini menggunakan metode analisis interpretatif yang dimaksudkan untuk mendapatkan makna terhadap obyek-obyek, peristiwa, dan tindakan aktor. Data utama diperoleh melalui wawancara mendalam kepada sejumlah sumber data, kemudian ditunjang dengan studi pelacakan dari berbagai literatur dan sumber-sumber pengkajian yang relevan dengan permasalahan penelitian. Dari hasil penelitian dipahami bahwa gerakan penegakan syariat Islam di Makassar dalam periode tersebut sangat kuat dipengaruhi oleh serangkaian formasi politik dominan, baik yang berasal dari faktor eksternal maupun internal yang begitu kuat mempengaruhi semangat dan perilaku para aktifis pro syariat Islam. Bagian lainnya yang tidak kalah menarik adalah memahami strategi yang dibangun oleh para aktifis tersebut dalam rangka memperkuat soliditas formasi politik Islam lokal di Makassar dalam rangka menjamin keberlangsungan gerakan tersebut. Disini terlihat bahwa gerakan penegakan syariat Islam di Makassar dibangun secara sangat rapih dan modern berdasar kepada basis sebuah gerakan sosial yang massif.
\end{abstract}

Kata kunci: syariat Islam, formasi politik, strategi gerakan.

\begin{abstract}
This study explored the politic of Islamic law enforcement in Makassar in the period 2001-2005. This study used interpretive analysis intended to get the meaning of objects, events, and actions of doers. The primary data obtained through indept interviews to a number of data sources, then supported with tracer studies from a variety of literature and resources that relevant to the research problems. From the research, it can be known that the Islamic law enforcement in Makassar was strongly affected by a dominantly political formation, both from external and internal factors which so strongly affected the spirit and the action of the Islamic law activists. Another interseting part was to understand the strategy built by the activists to strengthen the solidity of the local Muslim political formations in Makassar to ensure the sustainability of the movement. The research shows that the movement of the Islamic law enforcement in Makassar was built very neatly and modern way based on a massive social movement.
\end{abstract}

Keywords: Islamic law, political formation, strategy of movement. 


\section{PENDAHULUAN}

$\mathrm{K}$ iprah fenomenal dari kelompok gerakan yang menamakan dirinya Komite Persiapan Penegakan Syariat Islam (KPPSI) di Makassar berkembang dengan sangat cepat. Organisasi gerakan ini merupakan salah satu wadah umat Islam Sulawesi Selatan dalam merancang, mengorganisir dan menyebarkan gagasan penerapan syariat Islam, lahir dan dideklarasikan pada tanggal 15 April 2001 di Makassar. Pada awalnya mungkin tidak ada yang menduga kalau ikhtiar sekelompok muslim Sulawesi Selatan yang terhimpun dalam Komite Persiapan Penegakan Syariat Islam (KPPSI) yang memperjuangkan penerapan syariat Islam akan menjadi fenomenal. Dalam tempo yang relatif singkat kelompok ini mampu menjadi pusat perhatian, baik dari kelompok pemerintah, tokoh agama, maupun dari lapisan masyarakat umum. Dalam keberadaannya, KPPSI menjadi sentra sorotan oleh hampir semua kalangan.

Makassar khususnya dan Sulawesi Selatan pada umumnya merupakan salah satu daerah yang dipandang sangat antusias untuk menerapkan syariat Islam pasca terjadinya reformasi. Isu penerapan Syariat Islam di Sulawesi Selatan digulirkan oleh KPPSI sebagai organisasi induk dari berbagai organisasi dan kelompok yang concern dalam gerakan penegakan syariat Islam. Kehadiran KPPSI di era reformasi dipandang sebagai refleksi sosial kelompok mayarakat Sulawesi Selatan atas kerinduannya terhadap suatu sistem hukum yang bernafaskan Islam. Selain itu, juga dipandang sebagai kekuatan politik arus bawah yang dapat menjadi kekuatan perubah terhadap tatanan nilai yang tidak bersahaja. Agenda utama KPPSI adalah penerapan syariat Islam di Sulawesi Selatan (Darwis, tth:1).

Gerakan ini didukung oleh fakta bahwa suku Bugis dan Makassar sebagai suku mayoritas masyarakat Sulawesi Selatan telah lama dikenal sebagai penganut ajaran Islam yang kuat. Ada banyak fakta sejarah yang memperkuat argumentasi tersebut yaitu bahwa mayoritas kerajan-kerajaan yang pernah ada di Sulawesi Selatan berdiri dan tumbuh kuat dalam budaya tradisional Islam yang kental, meskipun masyarakat Sulawesi Selatan menjunjung tinggi kebhinekaan Indonesia setelah merdeka, kondisi tersebut tetap bertahan dalam berbagai ritus adat dan tradisi masyarakatnya. Inilah yang menyebabkan KPPSI begitu mudah mendapat tempat di hati warga Makassar. Meskipun harus diakui bahwa tidak semua warga Makassar setuju dan mendukung gerakan penegakan syariat Islam yang diusung oleh KPPSI.

Dalam konteks tersebut, lahirnya gerakan politik penegakan syariat Islam yang diusung oleh KPPSI di kota Makassar telah melahirkan identitas politik tersendiri yang sekaligus melahirkan sebuah tanda tanya besar tentang formasi politik apa sebenarnya yang berperan besar dalam menyediakan ruang bagi munculnya gerakan penegakan syariat Islam di kota Makassar. Diyakini bahwa formasi politik tersebut tidaklah tunggal, faktor politik lokal, nasional, serta global, berjalan bersama membentuk formasi induk menyemai benih-benih ideologi serta gerakan yang tumbuh subur dalam langgam perilaku politik Islam lokal di kota Makassar.

Pada akhirnya ditengarai pula bahwa pendekatan perilaku dan strategi dari gerakan tersebut memiliki dampak yang sangat kuat bagi terbentuknya formasi politik Islam lokal di kota Makassar. Sehingga dalam memahami fenomena gerakan penegakan syariat Islam di kota Makassar tidak bisa dilihat secara monolitik, baik aktor maupun faktor telah bermetamorfosa dalam bentuk yang beragam. Fenomena ini oleh peneliti kemudian menjadi menarik untuk ditelusuri lagi, guna mendapatkan makna di balik fakta yang merefleksikan apa dan bagaimana isu penegakan syariat Islam muncul dan berkembang di tengah arus pertarungan politik era reformasi.

Dari rangkaian pemaparan pada latar belakang masalah di atas, maka pertanyaan penelitian adalah: 1) Formasi politik apakah yang mempengaruhi secara sistemik lahirnya gerakan penegakan syariat Islam di Makassar? 2) Bagaimanakah strategi gerakan penegakan syariat Islam tersebut dalam memperkuat formasi politik Islam lokal di Makassar?

Tujuan penelitian ini adalah berusaha mengembangkan pengkajian teoritis bagi para peneliti yang memiliki concern terhadap perkembangan politik Islam. Di samping itu, juga bertujuan mencari alternatif yang mencerahkan dalam memahami terminologi Syariat Islam sebagai bagian dari entitas politik yang plural di era demokrasi.

\section{METODE PENELITIAN}

Penelitian ini menggunakan metode analisis interpretatif yang dimaksudkan untuk mendapatkan makna serta analisis terhadap obyekobyek, peristiwa, dan tindakan aktor. Data utama 
diperoleh melalui wawancara mendalam (indept interview) (Sugiyono:2006) terhadap informan yang telah ditentukan sebelumnya, kemudian ditunjang dengan studi pelacakan (tracer study) dari berbagai literatur dan sumber-sumber pengkajian yang relevan dengan permasalahan penelitian.

\section{PEMBAHASAN}

\section{Formasi Politik Penyebab Lahirnya Gerakan Penegakan Syariat Islam}

Motif politik yang mempengaruhi lahirnya gerakan penegakan syariat Islam di kota Makassar selama kurun waktu 2001-2005 dapat dipahami dengan mengurai satu persatu formasi politik dominan sebagai triger dalam membangun gerakan penegakan syariat Islam:

\section{Manifestasi Politik Otonomi Daerah}

Dalam pandangan KPPSI kota Makassar, fenomena otonomi daerah memiliki makna yang sangat signifikan dalam hal aspirasi dan kebebasan berekspresi warga negara. Seperti halnya di sejumlah daerah di Indonesia, seperti Riau, dan Banten, tuntutan pemberlakuan syariat Islam di Sulawesi Selatan digulirkan oleh kelompok-kelompok Islam lokal, yang kemudian didukung oleh para tokoh politik dan pemuka agama lokal, dan bahkan juga oleh Pemda sendiri.

"Fakta sosial bahwa umat Islam di Sulawesi Selatan adalah mayoritas, maka sangat wajar mereka juga berhak menjalankan syariat agamanya. Apalagi juga setelah reformasi ini, situasi politik sudah berubah, sehingga peluang Sulawesi Selatan untuk mendapatkan otonomi khusus bagi penegakan syariat Islam misalnya sangat terbuka" (Kaimuddin, Wawancara 13 November 2014).

Isu syariat Islam terutama berkembang semenjak pemberian Otonomi Khusus kepada Aceh untuk penegakan syariat Islam. Seiring dengan itu, sejumlah Pemerintah Daerah, dalam semangat penegakan syariat Islam, juga mulai membuat peraturan-peraturan daerah yang berlandaskan syariat. Ini terlihat selain di Sulawesi Selatan khususnya Makassar, juga di Riau, Banten, Cianjur, Garut, Tasikmalaya, Indramayu, Pamekasan, dan beberapa daerah lainnya. Pengundangan peraturan daerah dan pencanangan penerapan syariat Islam di berbagai daerah tersebut, sebagian juga dilakukan karena tekanan unsur-unsur masyarakat lokal, dan sebagian lagi dilakukan dengan harapan bisa mereformasi masyarakat (Taufiq Andnan Amal \&
Samsu Rizal Pangabean, 2004: 59).

Sehingga dengan demikian, pelaksanaan syariat Islam di Aceh, yang telah diakomodasi Pemerintah Pusat melalui Undang-Undang No. 44 Tahun 1999, dalam tingkatan ide, dapat dikatakan sebagai tonggak awal dan telah memicu daerah lain untuk menuntut hal yang sama (yang tentu saja tuntutannya berbeda berdasarkan perbedaan demografi, agama, dan budaya setempat, baik pada level daerah tingkat I maupun pada level daerah tingkat II) (Jamhari \& Jajang Jahroni, 2004: 41). Menurut para aktifis pendukung syariat Islam di Makassar, hak melaksanakan syariat Islam itu hendaknya tidak menjadi hak eksklusif masyarakat Aceh semata sebagai sebuah daerah istimewa, melainkan dikembangkan menjadi hak setiap daerah yang memiliki kesiapan untuk menerapkan hukum yang beragam bagi warganya yang berbeda agama (Kaimuddin, Wawancara 13 November 2014).

\section{Revitalisasi Identitas Politik Islam}

Dalam pandangan KPPSI, representasi politik melalui jalur partai politik Islam dianggap tidak efektif lagi sebagai alat untuk mempertahankan identitas politik umat Islam di Sulawesi Selatan. Oleh sebab itu diperlukan revitalisasi identitas politik yang kemudian menemukan pangkalnya yaitu kembali kepada syariat Islam sebagai sumber asasi kehidupan masyarakat muslim.

"Umat Islam Indonesia yang begitu besar secara kuantitas tidaklah dengan serta merta menjadikan kepentingan Islam sebagai bagian penting dalam kebijakan negara. Sebaliknya terjadi depolitisasi terhadap umat Islam di masa lalu telah membuat umat Islam kehilangan arah" (Kaimuddin, Wawancara 13 November 2014).

Menurut Abdullah Ahmad Na'im, identitas memiliki arti penting dalam politik sebagian besar masyarakat manusia. Islam politik adalah sebuah bentuk mobilisasi identitas Islam dalam rangka mencapai sasaran-sasaran kebijakan publik. Identitas Islam selalu integral dalam politik muslim (Bassam Tibi, 1999: 203-194). Na’im juga menjelaskan bahwa di kalangan Islam politik seperti yang dipraktekkan di beberapa negara Islam seperti Iran dan Sudan, apa yang dituntut mereka bukan hanya penegakan syariat Islam secara tegas, tetapi juga legitimasi bagi tindakan-tindakan tertentu untuk menentang penyimpangan dan melawan ancaman (Abdullah 
Ahmad Na’im dalam Peter L Berger, 2003: 186).

Komite Perjuangan Penegakan Syariat Islam (KPPSI) adalah representasi dari entitas Islam politik berperan sebagai maskot gerakan penegakan syariat Islam di kota Makassar, berusaha merestorasi kembali ide pemberlakuan syariat Islam dalam sistem ke-Indonesiaan khususnya di Sulawesi Selatan dan sekitarnya, sebagaimana yang pernah tercetus dalam Piagam Jakarta di masa-masa awal pembentukan republik ini.

"Fakta sejarah menunjukkan bahwa Piagam Jakarta adalah hasil kesepakatan awal pendirian bangsa ini, meskipun pada akhirnya sila pertama dari Piagam Jakarta itu diubah bunyinya menjadi Ketuhanan Yang Maha Esa, padahal awalnya berbunyi Ketuhanan Dengan Kewajiban Menjalankan Syariat Islam Bagi Pemeluk-Pemeluknya" (Kaimuddin, Wawancara 13 November 2014).

Dengan menggunakan legitimasi Islam, para pelaku Islam politik seringkali mengajukan pertanyaan: mengapa masyarakat Islam gagal mewujudkan identitas Islam dan implementasi syariat sebagai jalan hidup yang telah ditetapkan Tuhan, padahal umat Islam telah mendapatkan kemerdekaan sejak beberapa dekade yang lalu? Mengapa umat Islam hanya besar dalam kuantitas tapi tidak unggul dalam kualitas? (Muhammad Alfan Alfian Mallarangeng dalam Kurniawan Zein dan Sarifuddin HA (editor), 2001: 72).

\section{Respon Terhadap Kegagalan Negara}

Desakan ke arah penerapan syariat Islam di era awal reformasi juga terkait dengan keadaan politik di Indonesia, yang dipandang tidak layak bagi kehidupan sosial dan politik yang damai dan aman. Bayang kediktatoran yang belum sirna sepenuhnya, penindasan negara, kurangnya pelembagaan demokrasi, ketiadaan keadilan hukum dan sosial, kegagalan model-model pembangunan yang tidak sensitif terhadap budaya lokal, dan dominasi kepentingan negara-negara besar turut menciptakan munculnya tuntutan-tuntutan yang radikal dan militan di bidang penerapan sistem syariat Islam.

Begitu pula dengan terjadinya krisis multidimensional dan berbagai peristiwa di tanah air yang tidak segera terselesaikan membuat negara tidak mampu memberikan rasa aman kepada warganya, bahkan negara terkesan lambat dan masa bodoh dengan berbagai konflik kekerasan yang bersifat horizontal, seperti di Ambon, Poso, Sambas, Sampit, dan sebagainya. Dari sana, warga negara akhirnya tidak percaya lagi pada negara, dan mereka mengambil inisiatif sendiri untuk menyelesaikannya.

Kegagalan negara mengelolah sumber daya yang plural itulah sebenarnya yang merupakan pangkal dari kekisruhan sosial di Indonesia. Negara tidak kuasa menjadi jaring pengaman atas gejolak sosial yang sudah membara belasan tahun lamanya, sehingga begitu ada sulutan bahan bakar dengan sekejap kemudian terbakar. Negara gagal menjadi perekat sosial kemasyarakatan, karena negara tidak memperhatikan dinamika sosial yang terus berkembang.

Negara dalam hal ini hanya menjadi "matamata", bagaimana warga negara yang bergejolak nanti akan ditindak, ditangkap, dan diadili oleh negara dengan caranya sendiri, bukan dengan cara mereka rakyat. Akibatnya jelas, warga negara terus bergejolak, memberontak, dan beberapa lainnya ingin merdeka seperti Papua, Riau, Makassar, dan Banten (Zuly Qadir, 2004: 82).

Dalam uraian Louay M Shafi, dorongan ke arah Islamisasi meningkat setelah intelektual muslim menyadari bahwa ideologi-ideologi pembangunan yang diterapkan penguasa-penguasa muslim tidak menghasilkan kemajuan dalam kehidupan politik dan sosial masyarakat-masyarakat muslim. Justru yang dihasilkan oleh ideologi pembangunan tersebut adalah bercokolnya kekuasaan kelas penguasa yang mementingkan diri sendiri dan hidup mewah. Di masyarakat-masyarakat muslim pasca kolonial, elit yang berkuasa berusaha, dan berhasil memperkaya diri dan kroni-kroni mereka di tengah-tengah kemiskinan masyarakat luas (Taufik Adnan Amal dan Syamsu Rizal Panggabean, 2004:59).

Pujian bahwa Indonesia merupakan miniatur pertemuan semua agama yang menampilkan semangat pluralitas, dan meluasnya ideologi toleransi berkat kuatnya pengaruh Islam kultural yang mengedepankan semangat inklusivitas, toleransi, dan perlunya prinsip keadilan menjadi dasar penegakan hukum seolah-olah telah sirna pasca orde otoriter. Maka munculnya kehendak menerapkan syariat Islam juga didorong oleh pandangan bahwa penerapan syariat Islam dapat menjadi alternatif yang efektif untuk mengatasi segala persoalan hidup masyarakat.

Sementara di sisi lain, negara terkesan bingung dalam menemukan terapi yang tepat bagi segala persoalan yang dihadapi masyarakat. Hal ini 
sekaligus menjadi tamparan atas kegagalan negara dalam merekonstruksi kembali lembaga sosial dan politik pasca kediktatoran rezim sebelumnya. Dalam konteks ini, syariat Islam telah dipandang sebagai obat yang menyembuhkan segala macam penyakit Indonesia. Syariat Islam dalam pengertian ini lebih mirip sebagai konstruk kekecewaan dan ketidakpercayaan masyarakat terhadap negara yang dirasa sudah tidak berdaya (stateless) (Kaimuddin, wawancara 13 November 2014).

\section{Strategi Memperkuat Formasi Politik Islam Di Makassar}

Untuk mengetahui bagaimana dampak dari munculnya gerakan penegakan syariat Islam terhadap penguatan formasi politik Islam lokal di Makassar, penulis mencoba memetakan strategi gerakan penegakan syariat Islam oleh KPPSI dalam sebuah pendekatan teoritis, yaitu bahwa strategi gerakan penegakan syariat Islam oleh KPPSI akan dijelaskan secara spesifik dengan menggunakan konsepsi Sidney Tarrow tentang pola gerakan social (Sidney Tarrow, 1994: 81).

\section{Merancang Tindakan Kolektif}

KPPSI pada dasarnya ingin dijadikan sebagai kelompok koalisi, atau kelompok aliansi bagi kelompok-kelompok serupa yang ingin memperjuangkan penerapan syariat Islam, maupun untuk merangkul organisasi-organisasi Islam yang sejauh ini masih enggan dengan ide penerapan syariat Islam di Indonesia dan khususnya di kota Makassar. Dengan kata lain, nantinya KPPSI dapat menjadi wadah bersama gerakan penegakan syariat Islam, sehingga ke depan tidak ada sekat antara Muhammadiyah dan NU, atau pun organisasi Islam lainnya dalam hal perjuangan Islam (Kaimuddin, wawancara 13 November 2014).

Keinginan ke arah itu setidaknya dapat terlihat dari kehadiran berbagai utusan dalam kongres pertama KPPSI di Makassar pada tahun 2001 silam, yang sekaligus sebagai tonggak pendirian KPPSI. Dengan demikian, organisasi ini ke depan dirancang dapat menjadi "kendaraan" bersama dalam memperjuangkan tegaknya syariat Islam di kota Makassar yang pada dasarnya terdiri dari berbagai suku dan golongan (Jamhari dan Jajang Jahroni, 2004: 21-22).

Strategi aliansi ini menegaskan bahwa para aktifis KPPSI menyadari bahwa perjuangan untuk menerapkan syariat Islam di Makassar harus terkumpul dalam satu koordinasi meskipun datang dari berbagai kelompok yang berbeda. Maka gerakan penegakan syariat Islam tidak dibiarkan terjadi tanpa diakomodasi ke dalam suatu institusi gerakan yang utuh, karena jika yang terjadi sebaliknya segencar apa pun upaya yang dilakukan bagi penegakan syariat Islam tidak mungkin akan tercapai (Kaimuddin, wawancara 13 November 2014).

Alasan lainnya adalah bahwa dengan strategi koalisi ini, kemampuan dalam mengembangkan jaringan yang lebih luas dan konsolidasi sumber daya gerakan akan lebih mudah dilakukan. Tujuannya adalah bahwa penegakan syariat Islam lebih mungkin tercapai bila dilakukan dari tahap terbawah (tingkat desa/kelurahan) terlebih dahulu (bottom up) yang kemudian akan berakhir pada tingkatan lokal Makassar secara keseluruhan.

Maka untuk mendukung konsolidasi strategi gerakan yang berbasis pada prinsip aliansi/koalisi tersebut, KPPSI mengembangkan pola dukungan terhadap gerakan penegakan syariat Islam secara fleksibel. Ini dimaksudkan guna memperluas basis massa lintas kelompok dan organisasi serta sekaligus menciptakan iklim solidaritas yang interdependen di antara para pendukung gerakan. Dengan menciptakan iklim solidaritas yang tinggi di antara para pendukung gerakan, gerakan penegakan syariat Islam diharapkan menjadi lebih kuat dan efektif (Sidney Tarrow, 1994: 81).

Sehingga dapat dijelaskan di sini bahwa KPPSI terbuka bagi semua kalangan dengan tidak menerapkan pola keanggotaan tertentu (Kaimuddin, wawancara 13 November 2014). Setiap umat Islam, baik masyarakat umum maupun mereka yang menjadi anggota berbagai parpol, ormas, gerakan, dan berbagai bentuk organisasi Islam lainnya, dapat diakomodir ke dalam barisan gerakan ini. Satu-satunya syarat terpenting adalah adanya prinsip kesepahaman dengan misi KPPSI, terutama mendukung upaya penerapan syariat Islam secara utuh.

\section{Melakukan Tindakan Kolektif}

Para aktifis KPPSI Makassar memilih untuk melakukan advokasi penerapan syariat Islam di Indonesia dengan membangun wacana publik (public opinion) lewat tulisan-tulisan, baik lewat media cetak dan elektronik, maupun lewat jaringan internet atau bahkan penerbitan buku, (Kaimuddin, wawancara 13 November 2014) serta berbagai diskusi dan seminar ilmiah dengan sejumlah kalangan, baik dari kalangan akademisi kampus maupun dengan 
para intelektual yang berbasis di organisasi massa Islam. Sebagai ajang sosialiasi, mereka juga aktif melakukan pembangunan relasi, baik di lingkungan kampus atau pun dengan para aktifis masjid-masjid tentang perlunya pelaksanaan syariat Islam di kota Makassar (Jamhari dan Jajang Jahroni, 2004:21). Di samping itu, mereka juga aktif melakukan lobi-lobi politik kepada partai-partai Islam di DPRD untuk diteruskan kepada DPP masing-masing partai agar dapat memperjuangkan Piagam Jakarta pada tingkat nasional lewat sidang-sidang resmi DPR di parlemen. Salah satunya pada 15 Agustus 2001, saat berlangsungnya Sidang Paripurna DPR RI.

Selain bergerak dengan strategi-strategi konkret seperti di atas, KPPSI Makassar juga aktif membangun terobosan-terobosan kultural dalam rangka membangun opini publik tentang adanya serangan "musuh" terhadap Islam. Kecenderungan seperti ini mereka lakukan sebagian besar bersifat defensif dalam rangka memproteksi gerakan penegakan syariat Islam itu sendiri. Walaupun sebenarnya apa yang mereka lakukan itu belum tentu sudah sepenuhnya tepat, sebab bila mengkaji persoalan yang sebenarnya, akan terlihat bahwa persoalan tersebut tidak sesederhana yang mereka opinikan. Tapi setidaknya itulah karakteristik gerakan ini. Kebanyakan hal itu dilakukan lewat tulisan-tulisan yang mereka publikasikan.

\section{Memobilisasi Struktur}

Kemampuan KPPSI dalam memobilisir dukungan terhadap gerakan penegakan syariat Islam tidak hanya dilakukan terhadap kekuatankekuatan sosial politik lokal dan nasional semata, seperti usaha merangkul berbagai organisasi massa Islam dan partai politik Islam.

Usaha untuk mendapatkan dukungan gerakan juga diarahkan terhadap kekuatan gerakan Islam lainnya. Dalam lingkup nasional, KPPSI memiliki jaringan dengan organisasi pergerakan Islam lainnya seperti Front Pembela Islam (FPI), Laskar Jihad (FKAW Laskar Jihad), Hizbut Tahrir Indonesia (HTI), dan lain-lain. Di samping itu, mereka juga aktif melobi ormas-ormas Islam serta partai-partai Islam di DPRD bagi upaya penerapan syariat Islam.

Sedangkan mengenai hubungan KPPSI dengan partai-partai politik Islam yang ada saat itu. Sesungguhnya KPPSI tidak sepenuhnya percaya partai-partai tersebut bisa memenuhi tuntutan penegakan syariat Islam yang mereka maksud. Walaupun harus diakui bahwa PPP, PBB, dan PKS pernah memprakarsai upaya pengembalian Piagam Jakarta meski kemudian gagal.

Namun demikian, KPPSI tetap berusaha memberikan dukungan moral pada partaipartai Islam yang ada di DPRD untuk dapat mengakomodasi aspirasi penegakan syariat Islam, seperti dengan memperjuangkan pengembalian Piagam Jakarta dalam UUD 1945 (Jamhari dan Jajang Jahroni, 2004:80). Berbagai upaya dilakukan untuk itu, misalnya dengan cara mendatangi pemimpin-pemimpin partai Islam untuk diajak bertukar pikiran (audiensi) atau pun sekedar silaturrahmi biasa.

Selain itu, untuk menjaga kesinambungan gerakan dan dalam rangka mobilisasi dukungan tersebut, KPPSI selalu berusaha menghindari konflik internal dalam misi aliansi, maksudnya agar tidak menjadi bumerang bagi keberhasilan gerakan penegakan syariat Islam yang diupayakan. Untuk keperluan itu, organisasi gerakan dirancang secara fleksibel, tanpa mencampuri misi dan peran tersendiri mitra aliansi secara internal. Dengan pola ini, soliditas misi aliansi tetap terjaga, karena organisasi yang mejanjadi mitra aliansi merasa kepentingannya tidak diintervensi.

Alasan lainnya karena mereka secara organisatoris gerakan hanya membatasi tujuan gerakannya pada upaya penegakan syariat Islam (tathbiq syariah), KPPSI tetap memberikan keleluasaan dan kebebasan bagi organisasi pergerakan Islam lainnya untuk menjalankan program khas mereka masing-masing selama tidak bertentangan dengan syariat, seperti program FPI yang anti kemaksiatan, DDII yang corcern dengan dakwah dan anti aliran sesat, Muhammadiyah yang terkenal dengan gerakan sosial pendidikannya, dan lain-lain. Dalam konteks jaringan ini, KPPSI selalu melakukan koordinasi dan saling mengingatkan jika terjadi penyelewengan terhadap Islam (Jamhari dan Jajang Jahroni, 2004: 80).

Sehingga dengan demikian, strategi penegakan syariat Islam secara struktural terlihat lebih dominan dilakukan oleh KPPSI. Meskipun juga harus diakui bahwa strategi penegakan syariat Islam secara kultural melalui dakwak dan pembinaan akhlak masyarakat dari bawah, juga penting dan tidak dapat diabaikan. Namun yang perlu digarisbawahi bahwa upaya penegakan syariat Islam yang ditempuh dengan cara struktural tersebut, tahap operasionalnya meliput dua hal utama yaitu: Pertama, pembangunan dan penggalangan 
konsolidasi gerakan. Kedua, kristalisasi serta pembinaan kekuatan sosial politik yang ada.

Sebagai sebuah organisasi yang berbasis gerakan aliansi/koalisi, hal pertama yang dianggap perlu dilakukan oleh KPPSI ialah melaksanakan sosialisasi (dakwah) kepada segenap lapisan masyarakat lokal Makassar dan sekitarnya mengenai hikmah dan pentingnya pemberlakuan syariat Islam. Hal ini dimaksudkan untuk menyiapkan basis agar masyarakat siap menerima gagasan penerapan syariat Islam ketika perjuangan terhadap pemberlakuan syariat Islam itu telah sampai pada waktunya (Jamhari dan Jajang Jahroni, 2004:82).

Selanjutnya aksi atau strategi konkret yang telah dilakukan oleh KPPSI dalam memobilisasi upaya penegakan syariat Islam secara komprehensif -tentunya dalam tingkatan yang terkait dengan kebijakan politik pemerintah- kemudian dijalankan dan disesuaikan dengan cara mengikuti irama perkembangan politik, khususnya kebijakan pemerintah tentang otonomi daerah. Disadari bahwa kebijakan otonomi daerah dimanfaatkan sebagai jembatan praktis bagi upaya penerapan syariat Islam di beberapa daerah, khususnya di Makassar.

Nampak para aktifis KPPSI memahami bahwa tujuan penegakan syariat Islam akan efektif dilakukan dengan memanfaatkan sistem politikyang sedang berjalan. Seiring dengan telah bergulirnya kebijakan otonomi daerah sejak Januari 2001 silam. Beberapa daerah dan masyarakat Islam di Indonesia yang dinilai potensial selain Sulawesi Selatan, Banten, Tasikmalaya, dan Maluku memungkinkan dibuatnya Perda-Perda (Peraturan Daerah), seperti Perda Miras, yang korelatif dengan hukum syariat Islam.

Sedangkan dalam kaitannya dengan partaipartai politik Islam di parlemen (DPR RI dan DPRD) sebagaimana disinggung sebelumnya, KPPSI terus mendorong dan mendukung partai-partai tersebut untuk berusaha mengembalikan Piagam Jakarta ke dalam hukum dasar Negara Kesatuan Republik Indonesia yaitu ke dalam Mukaddima UndangUndang Dasar 1945.

\section{PENUTUP}

Dari kajian terhadap permasalahan formasi politik gerakan penegakan syariat Islam di Makassar dapat ditarik kesimpulan sebagai berikut ini:

Pertama, formasi politik dominan yang dianggap sebagai momentum bagi penegakan syariat Islam adalah pemberlakuan otonomi daerah yang mengakibatkan terjadinya keterbukaan politik masyarakat. Di samping itu, berkembang anggapan perlunya revitalisasi identitas politik Islam sebagai alat bargaining terhadap kekuasaan negara pasca otoriter. Keinginan menegakkan syariat Islam juga memiliki kaitan erat dengan situasi sosial politik nasional yang sedang mengalami disorientasi yang ditandai dengan lemahnya penegakan hukum, budaya KKN yang meluas, dekadensi moral masyarakat, serta berbagai persoalan politik dan ekonomi dalam skala besar, menyebabkan lahirnya sebuah asumsi bahwa negara telah gagal dalam melaksanakan misi mensejahterakan sebagaimana layaknya welfare state, Maka sebagian masyarakat kemudian mencari solusi alternatif mengatasi keadaan melalui penegakan syariat Islam.

Kedua, Para aktifis pro syariat di Makassar membangun serangkaian strategi agar tercipta kondusifitas politik lokal yang dapat menjamin kelanggengan gerakan penegakan syariat Islam. Dimulai dengan kalkulasi sistematis terhadap peluang dan tantangan yang muncul, kemudian merancang gerakan dan bertindak secara kolektif, serta memperkuat kemampuan dalam memobilisasi struktur yang bisa dimanfaatkan.

Pada intinya, strategi penegakan syariat Islam menurut KPPSI dilakukan secara struktural dan kultural. Meskipun diakui bahwa gerakan kultural melalui dakwak dan pembinaan akhlak masyarakat dari bawah mendapat porsi paling besar. Namun pendekatan struktural dilakukan melalui dua hal utama yaitu pembangunan dan konsolidasi sumber daya gerakan ke dalam berbagai lembaga dan organisasi. Kemudian kristalisasi serta pembinaan kekuatan sosial politik yang ada.

\section{UCAPAN TERIMA KASIH}

Terima kasih kepada tim redaksi Jurnal Litbang Kementerian Agama Makassar atas dimuatnya tulisan saya di Jurnal tersebut. Semoga Allah swt berkenan memberikan balasan yang setimpal. Amiin.

\section{DAFTAR PUSTAKA}

Amal, Taufik Adnan dan Samsu Rizal Panggabean. 2004. Politik Syariat Islam. Jakarta: Pustaka Alvabet.

Darwis, Muhammad, tth. Metodologi Dakwah KPPSI Dalam Upaya Penegakan Syariat Islam, Jurnal Al Tajdid Jurusan Dakwah dan Komunikasi 
STAIN Palopo.

Jacob, $\mathrm{T}$ (pengantar) dalam Widodo Usman dkk (editor). 2000. Membongkar Mitos Masyarakat Madani.Yogyakarta: Pustaka Pelajar.

Jamhari dan Jajang Jahroni (penyunting). 2004. Gerakan Salafi Radikal di Indonesia, Jakarta: PT Raja Grafindo Persada.

Mallarangeng, Muhammad Alfan Alfian dalam Kurniawan Zein dan Sarifuddin HA (editor). 2001. Syariat Islam Yes Syariat Islam No: Dilema Piagam Jakarta Dalam Amandemen UUD 1945. Jakarta: Paramadina.

Na'im, Abdullah Ahmad dalam Peter L Berger (editor), The Desecularization of the World: Resurgent Religion and World Politics, By Ethics and Public Policy Center, Wm. B. Eerdmans Publishing Co. 225 Jefferson Ave. S.E, Grand Rapids, Mich. 49503, (Terjemahan
Hasibul Khoir). 2003. "Kebangkitan Agama Menantang Politik Dunia".Yogyakarta: Arruz.

Qodir, Zuly. 2004. Syariah Demokratik: Pemberlakuan Syariat Islam di Indonesia. Yogyakarta: Pustaka Pelajar.

Sugiyono. 2006. Metode Penelitian Pendidikan Pendekatan Kuantitatif, Kualitatif,dan R \& D. Bandung: Alfabeta.

Tarrow, Sidney. 1994. Power in Movement: Social Movements, Collective Action and Politics. Melbourne, Australia: Cambridge University Press.

Tibi, Bassam.1998. The Challenge of Fundamentalisme: Political Islam and The New World Disorder. by the Regent of University of California, Terjemahan Imron Rosyidi dkk. 2000. Ancaman Fundamentalisme: Rajutan Islam Politik dan Kekacauan Dunia Baru. Yogyakarta: PT Tiara Wacana. 